\title{
Social Media in the Middle East: The Story of 2015
}
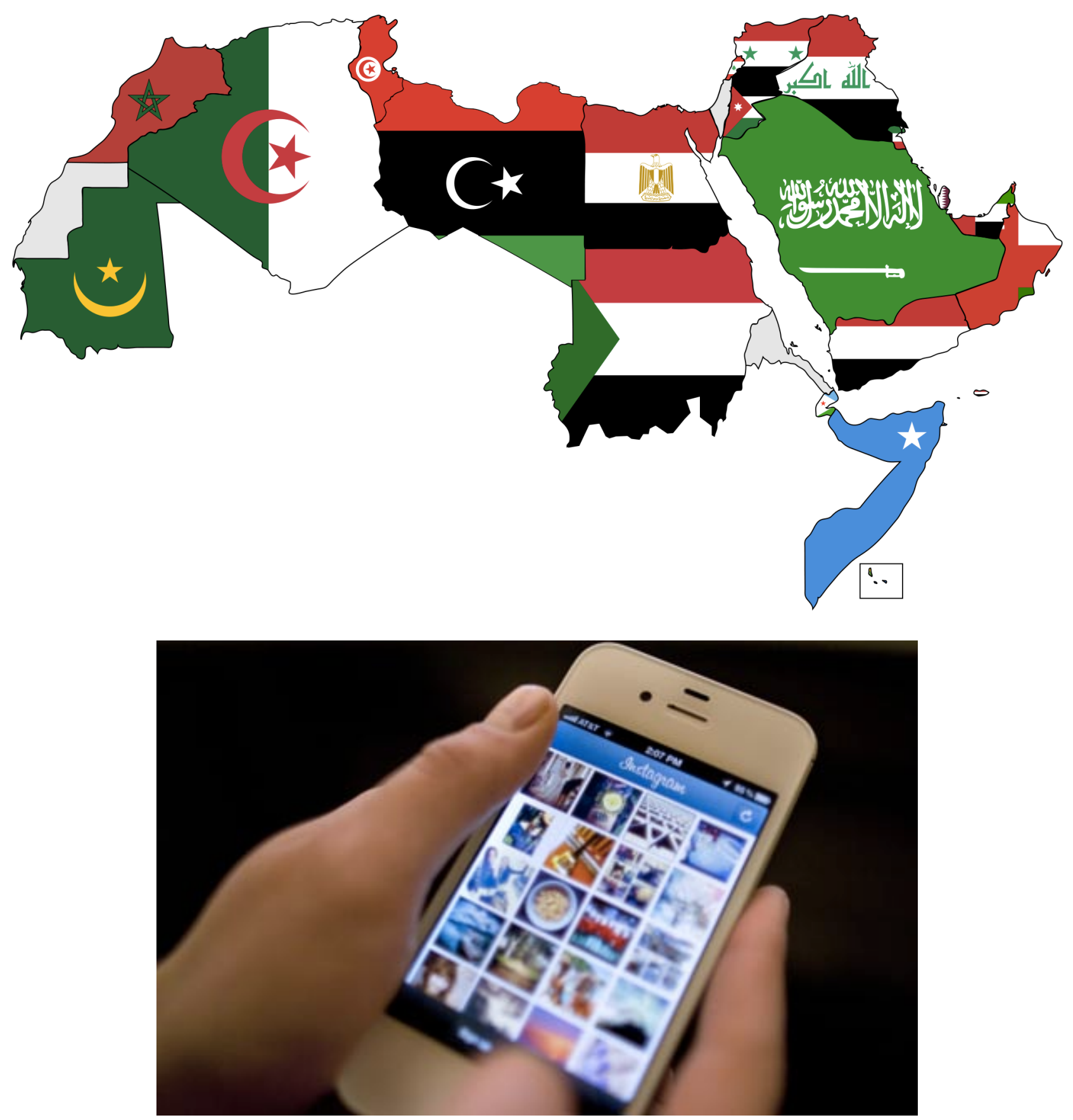

Damian Radcliffe 


\section{Table of Contents}

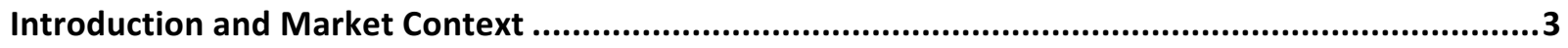

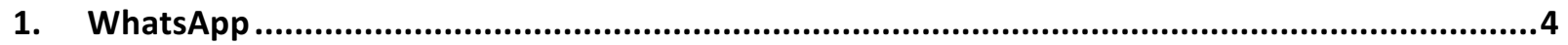

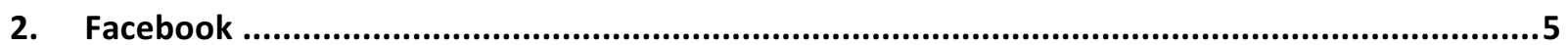

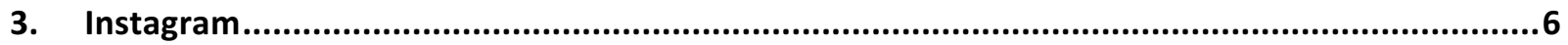

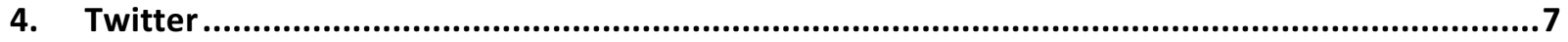

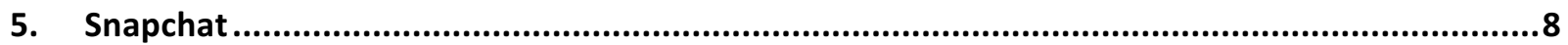

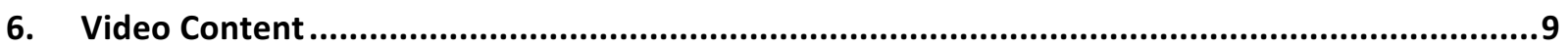

7. Social Media and Digital News consumption ......................................................................10

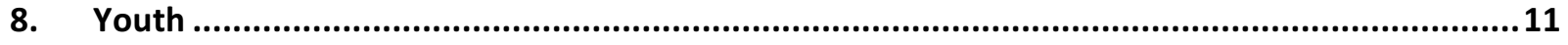

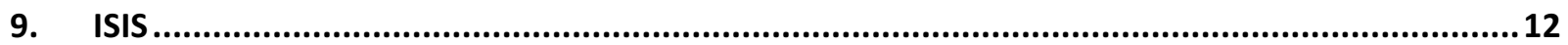

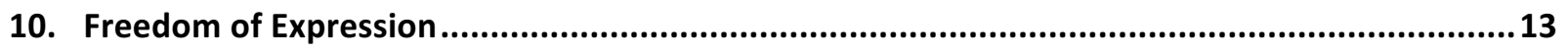

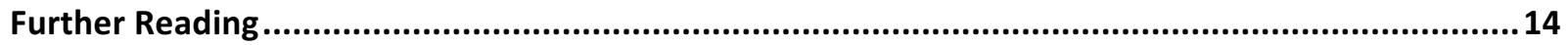

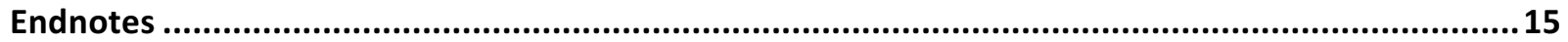

\section{About the Author}

Damian Radcliffe is the Carolyn S. Chambers Professor in Journalism at the University of Oregon.

He is also an Honorary Research Fellow at the Cardiff School of Journalism, Media and Cultural Studies, the UK's oldest journalism school; and a Fellow of the Royal Society for the encouragement of Arts, Manufactures and Commerce (RSA).

Over the past twenty years Damian has worked - and written - for some of the world's largest media brands including the BBC, the Guardian newspaper and The Huffington Post. Since December 2013 he has written a monthly column on tech, IT and telecoms in the Middle East for CBS Interactive / ZDNet.

Between 2012-14 he ran the Internet and Society (Rassed) research programme at Qatar's Ministry of Information and Communications Technology (ictQATAR), exploring the impact of the internet on society. The Rassed research has been viewed over 270,000 times on LinkedIn's SlideShare platform alone.

Other previous employers include Ofcom (the UK Communications Regulator) and the BBC.

You can view Damian's extensive writing and research portfolio at: www.damianradcliffe.com and he tweets@damianradcliffe. You can contact him through those channels or damian.radcliffe@gmail.com 


\section{Introduction and Market Context}

This report is the fourth in a series of annual reports designed to capture some of the key developments in the world of social media - within the Middle East - during the past twelve months. Interest in this field, which was first unlocked by the Arab Spring, continues to attract researchers, marketers and businesses.

The reasons for this are multiple: the region's "youth bulge" makes the market attractive for anyone seeking to attract a young tech-savvy audience, meanwhile the growth of ISIS - and their use of social media - continues to pose challenging questions for policy makers and freedom of speech advocates. ${ }^{1}$

These developments play out against a diverse backdrop, and this diversity results in wide variances in usage of social media and other digital technologies; with particular differences between the Gulf region and North Africa. In aggregate, regional usage of social media continues to be behind the global average.

Whatever else happens in 2016, this will continue to be a region where the rise of social will continue to attract considerable interest, not least because of the digital, socio-economic and political implications which these platforms can unlock. As these annual reviews show, this is an arena which does not stand still.

As ever, I hope you find this annual round-up as interesting and useful as I do.

Damian Radcliffe, January 2016

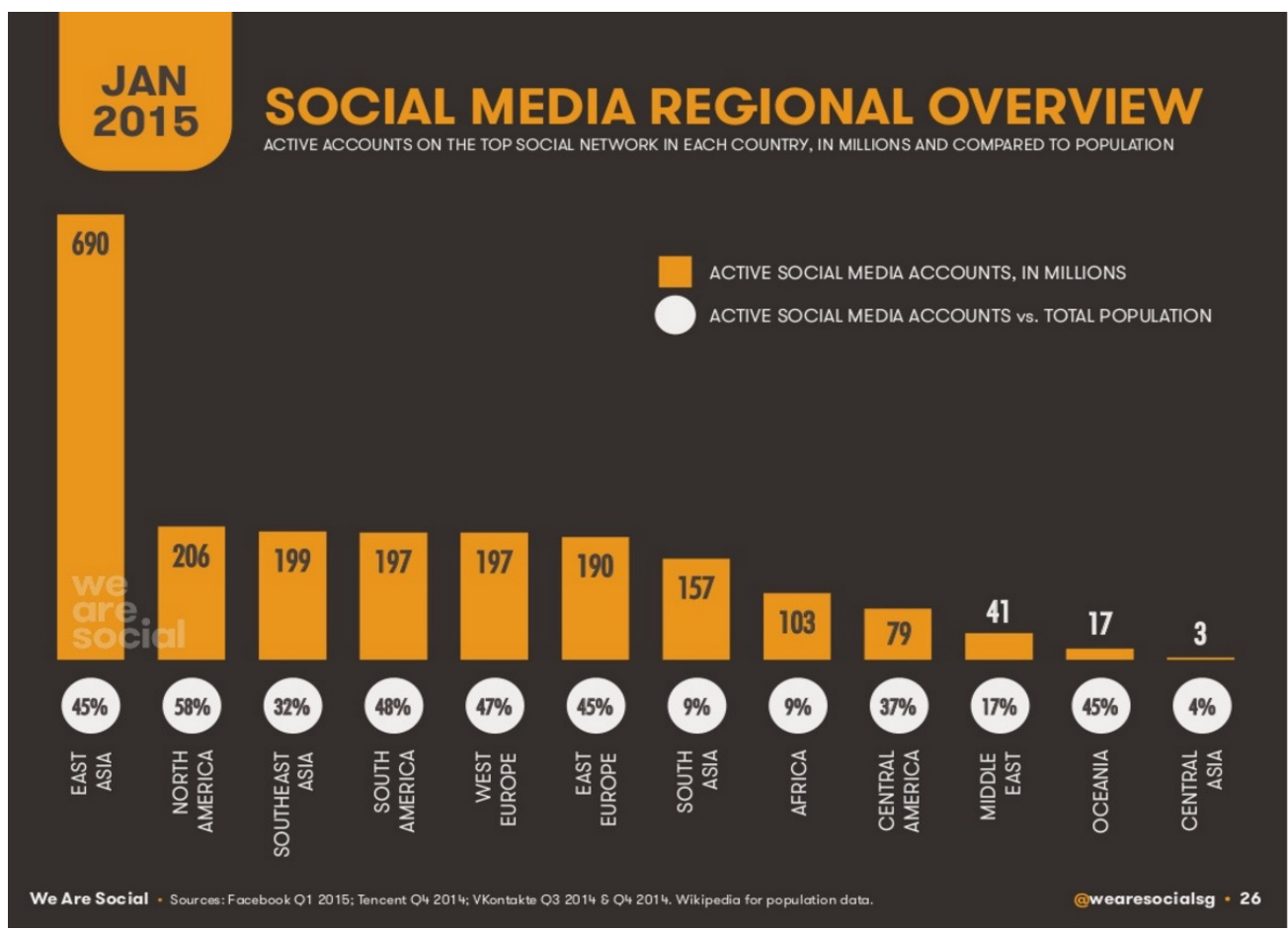

Figure 1: Social Media Regional Overview, via We Are Social $^{2}$ 


\section{WhatsApp}

- WhatsApp, the popular messaging service, is now the leading social media platform in Lebanon, Qatar, Saudi Arabia and UAE, according to data from Northwestern University in Qatar. ${ }^{3}$ The network was purchased by Facebook in 2014 for $\$ 19$ billion. Facebook also owns Instagram.

- WhatsApp is also the preferred social media channel for $41 \%$ of social media users in the region, research presented by TNS - at the Arab Social Media Influencers Summit in March 2015 - found. ${ }^{4}$

- $\quad 70 \%$ of Israelis say WhatsApp is the "mobile app they would not be able to do without." This is up from 54\% in 2013 - a survey by Bezeq, the largest telecommunications group in Israel, reported. ${ }^{5}$

\section{Top 3 Social media platforms per country, by percent used}

WhatsApp more popular than Facebook in most countries

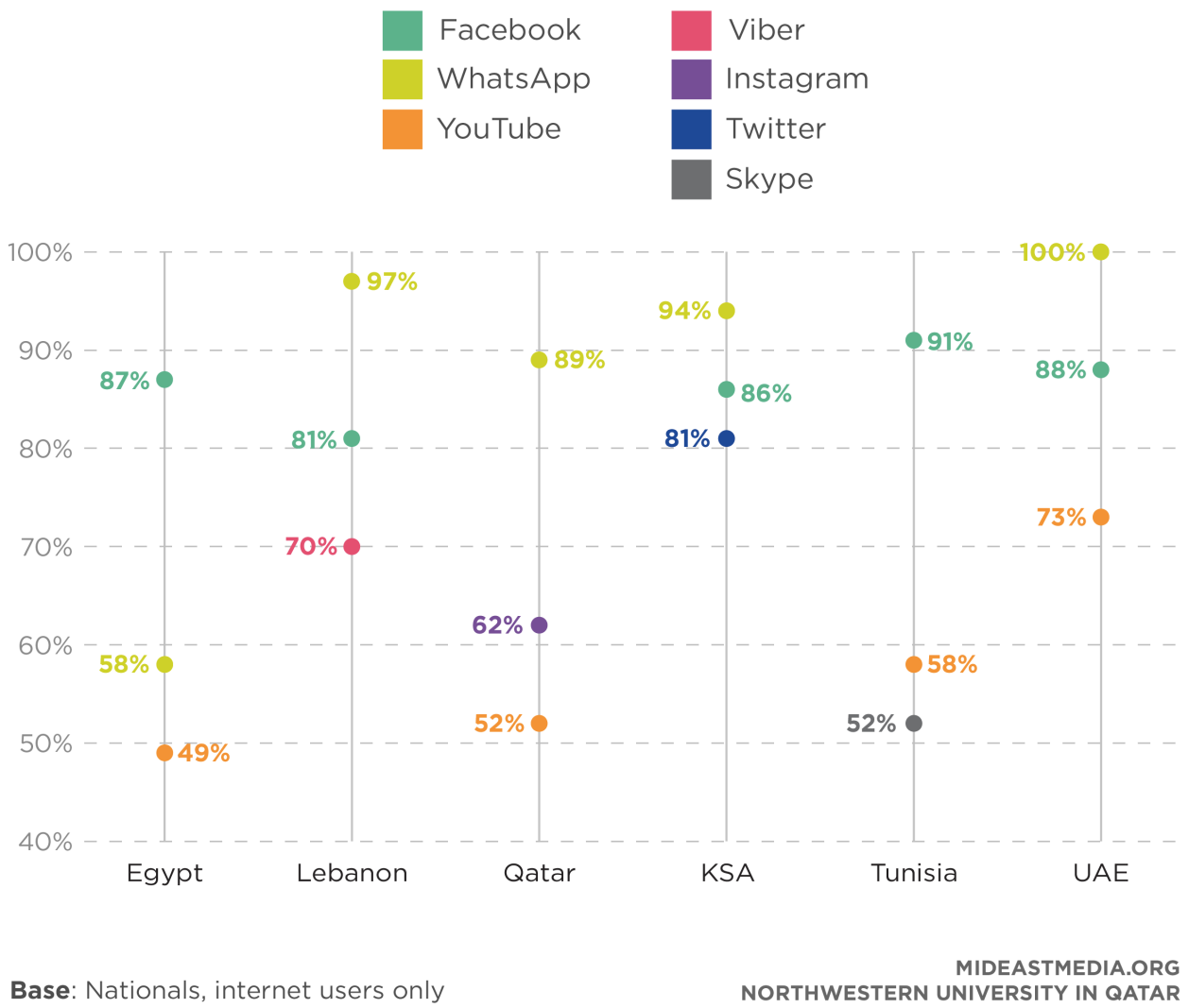

Figure 2: Top 3 social media platforms in six select countries, Northwestern University in Qatar 
- Across the region as a whole, however, Facebook continues to be the most used social network, with $80 \mathrm{~m}$ users at the start of $2015 .{ }^{6}$ There are $12 \mathrm{~m}$ users in Saudi Arabia and $11 \mathrm{~m}$ in Iraq. ${ }^{7}$ Egypt, with $27 \mathrm{~m}$ Facebook users, continues to have MENA's largest Facebook population. ${ }^{8}$

- TNS reported that $87 \%$ of social media users in the region are on Facebook; and $84 \%$ of these access the network via mobile devices. Meanwhile, $89 \%$ of MENA users log on to the site daily.

- Northwestern University in Qatar noted that Facebook usage among nationals had fallen in the past year, from $89 \%$ to $83 \%$, possibly as a result of migration to other channels such as Instagram.

- In November, questions were asked" about why Facebook launched it's "Safety Check" system when terrorists attacked Paris, but not when 41 people were killed in Beirut the day before. ${ }^{10}$

$\%$ of total users who are current subscribers in Facebook per country

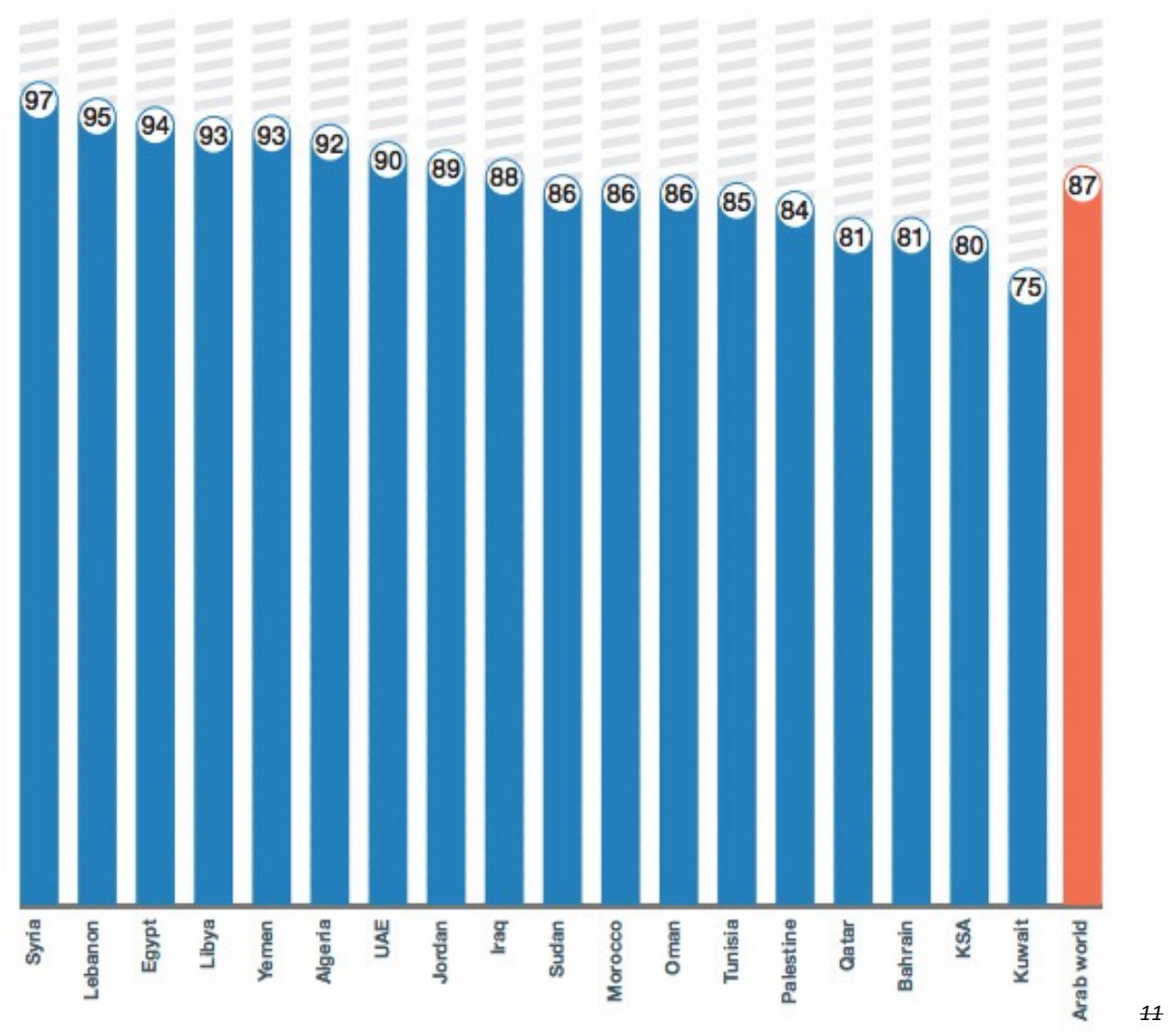

Figure 2: Facebook user penetration by \% of social media users, TNS Arab Social Media report 
- Instagram now has $25 \mathrm{~m}$ users in MENA ${ }^{12}$ and $400 \mathrm{~m}$ worldwide. ${ }^{13}$ Saudi Arabia has 10.7 million monthly active users, while there are 2.2 million monthly users in UAE and 3.2 million in Egypt. ${ }^{14}$

- Ipsos MENA reported in 2015 that during the previous year, usage of the network across their regional panel grew $+14 \%$, from $23 \%$ - $37 \%$ of panelists. ${ }^{15}$

- Instagram use has exploded among Arab Nationals, Northwestern University in Qatar revealed, growing from $6 \%$ of internet users in $\mathbf{2 0 1 3}$ to $\mathbf{2 8 \%}$ in $\mathbf{2 0 1 5}$, across their six nation study.

\section{Instagram}

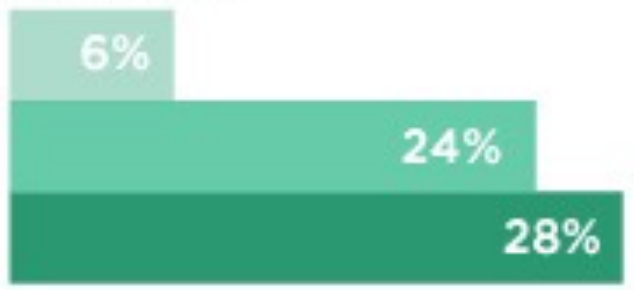

\section{Percent using social media platform}

Base: Nationals, internet user's only

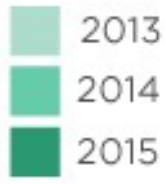

Figure 3+4: Nationals usage of Instagram, 2013-15 in Egypt, Lebanon, Qatar, Saudi Arabia, Tunisia and UAE, via Northwestern University in Qatar

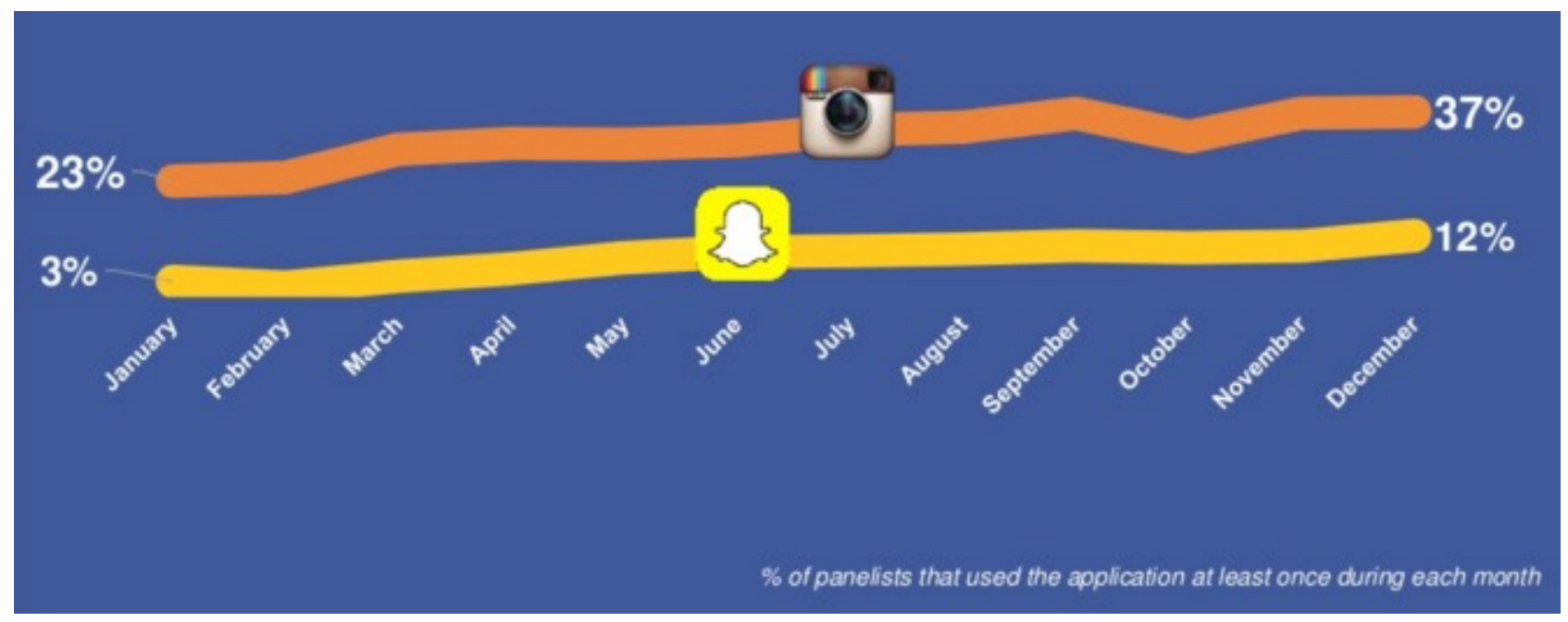

Figure 5: Growth of Instagram (and Snapchat) among Ipsos MENA panel during 2014 
4. Twitter

- Saudi Arabia and UAE continue to dominate MENA's Twitter market (53\% and 51\% of SM users in those countries have an account). Usage is lowest in Libya (12\%) and Syria (14\%), TNS discovered.

- But, daily usage is highest in Jordan, Libya, Palestine and Syria; and lowest in Saudi Arabia the same survey found; suggesting that despite lower Twitter penetration, users are more active.

- $\quad 45 \%$ of Twitter users are aged $\mathbf{1 8 - 2 4}$. Only a quarter (25\%) are aged $45+$, Northwestern University in Qatar noted in their latest media usage study.

- Saudi's Prince Alwaleed bin Talal attracted criticism ${ }^{16}$ after seeming to tweet an offer of a Bentley to each of the 100 Saudi pilots who took part in airstrikes in Yemen. ${ }^{17}$ The tweet is now deleted. ${ }^{18}$

\section{$\%$ of Twitter current subscribers who access it on daily basis per country}

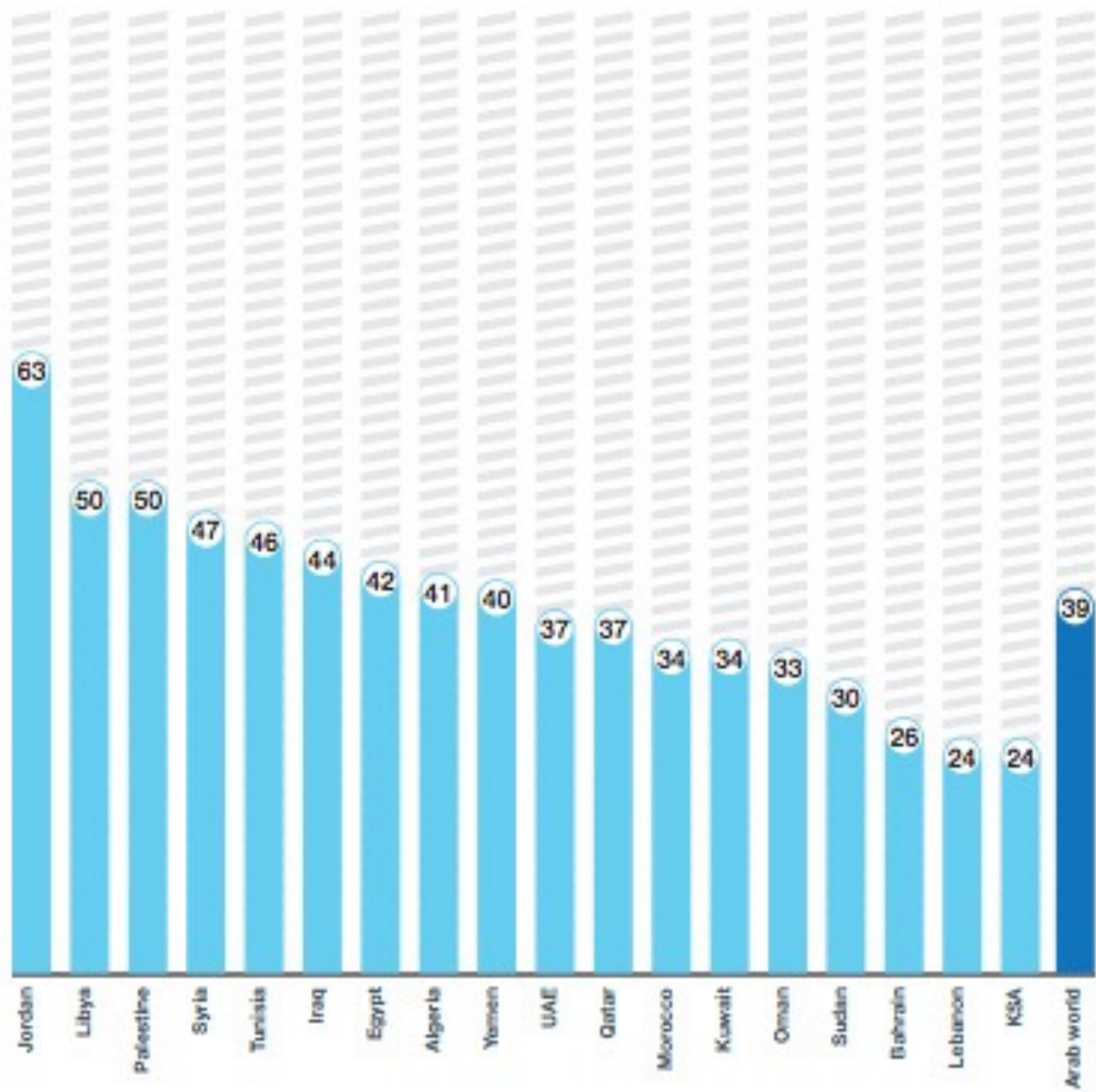

Figure 6: Percentage of Twitter users who access it daily per country (TNS) 
- The ephemeral and fast growing social network - usage grew from 3\% - 12\% of Ipsos MENA's panel in 2014 - featured Mecca on its "Live Stories" feed during Ramadan, giving non-Muslims a rare insight into the city (which non-Muslims cannot visit). The move came after c.300,000 people tweeted using the hashtag \#Mecca_live to get Snapchat to feature the Saudi city on their app. ${ }^{19}$

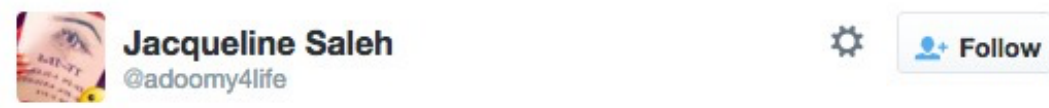

\section{I'm not muslim but seeing \#mecca_live made me think twice. Its beautiful People have really changed my perspective of islam}

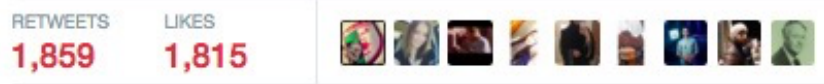

- Earlier in the year, some Snapchat and Twitter users in Saudi Arabia used \#RiyadhLife to poke fun $^{21}$ at life in the capital and stereotypes about the country. ${ }^{22}$

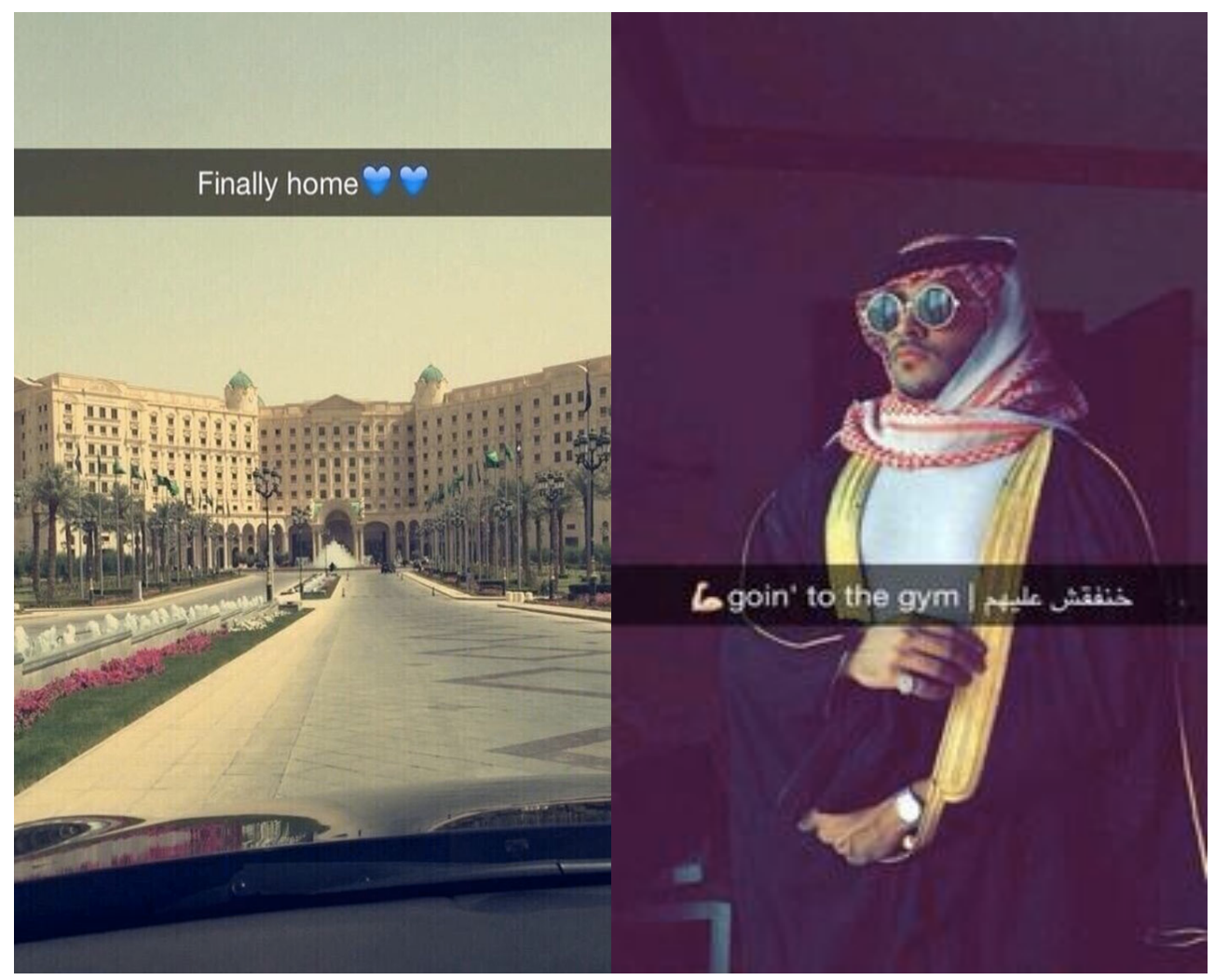

Figure 8: Examples of \#RiyadhLife 


\section{Video Content}

- MENA is the fastest growing consumer of videos on Facebook. Consumption - per head - of Facebook embedded videos in the region is twice the global average. ${ }^{23}$

- "Turkey is the second most active country in terms of Periscope streams, according to social analytics company Sysomos. And three of its cities - Istanbul, Ankara and Izmir - are among the top $\mathbf{1 0}$ cities with the most Periscope users, according to Twitter." (Buzzfeed, Sept 2015) ${ }^{24}$ Periscope, the live video streaming app, was launched by Twitter during March 2015. ${ }^{25}$

- Two-thirds (66\%) of social media users (based on a TNS sample of 7,000+ across 20 MENA countries) access YouTube daily. Daily log-ons are highest in Jordan (75\% and Palestine (74\%).

- Among Nationals, YouTube is the third most popular social channel ( $54 \%$ of internet users) after Facebook (83\%) and WhatsApp (77\%). Twitter and Viber rank next at 40\% (Northwestern in Qatar).

- Growth in watch time on YouTube is up over $80 \%$ year on year, Google data shows. ${ }^{26}$

The top trending YouTube videos for 2015, based on views, shares, comments and likes. ${ }^{27}$

1. طبارة (Pilot) by Danyah Cartoon

2. فر عون (Pharaoh) by Masameer

3. The Neighbours / الجير ان by Iftah Ya Simsim

4. Mother's Day / الأم عبد by Shady Srour

5. المزعج (Spam) by Eysh Elly

6. Temsa7ly / الشيلالية الر اتبية (Crocodile Episode 92) by Temsa7

7. حرة ضربة (Free kick) by Sa7i

8. ذحتي أبري (My Conscience) by SceenTV

9. Morning Routine / للمدرسة الصباحي روتيني by Hayla TV

10. Bean Boozled Challenge / المعفنة الحلاوة حدي المي by d7oomy999

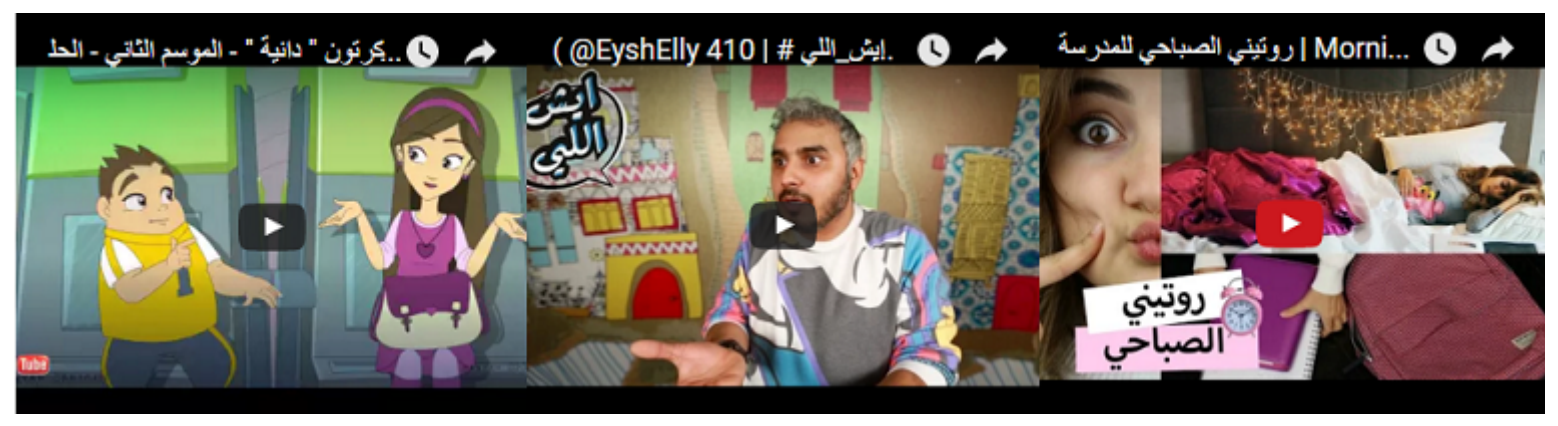

Figure 9: Images from some of the regions most popular YouTube videos in 2015 


\section{Social Media and Digital News consumption}

- $41 \%$ of Arab Youth say they use Facebook to share news articles with friends and family, reports the annual Arab Youth Survey. ${ }^{28} 75 \%$ read news online each week, just behind TV news viewing (79\%).

- Younger audiences value - and trust - social media as a source of news more than older audiences. Northwestern University revealed $53 \%$ of $18-24$ s consider social media reliable vs. $30 \%$ of those $45+$.

- This year the Wall Street Journal's Ahmed Al Omran hit 100k Twitter followers (he's now at 114k), reflecting the rising importance of social as a news source both inside - and outside - the region.

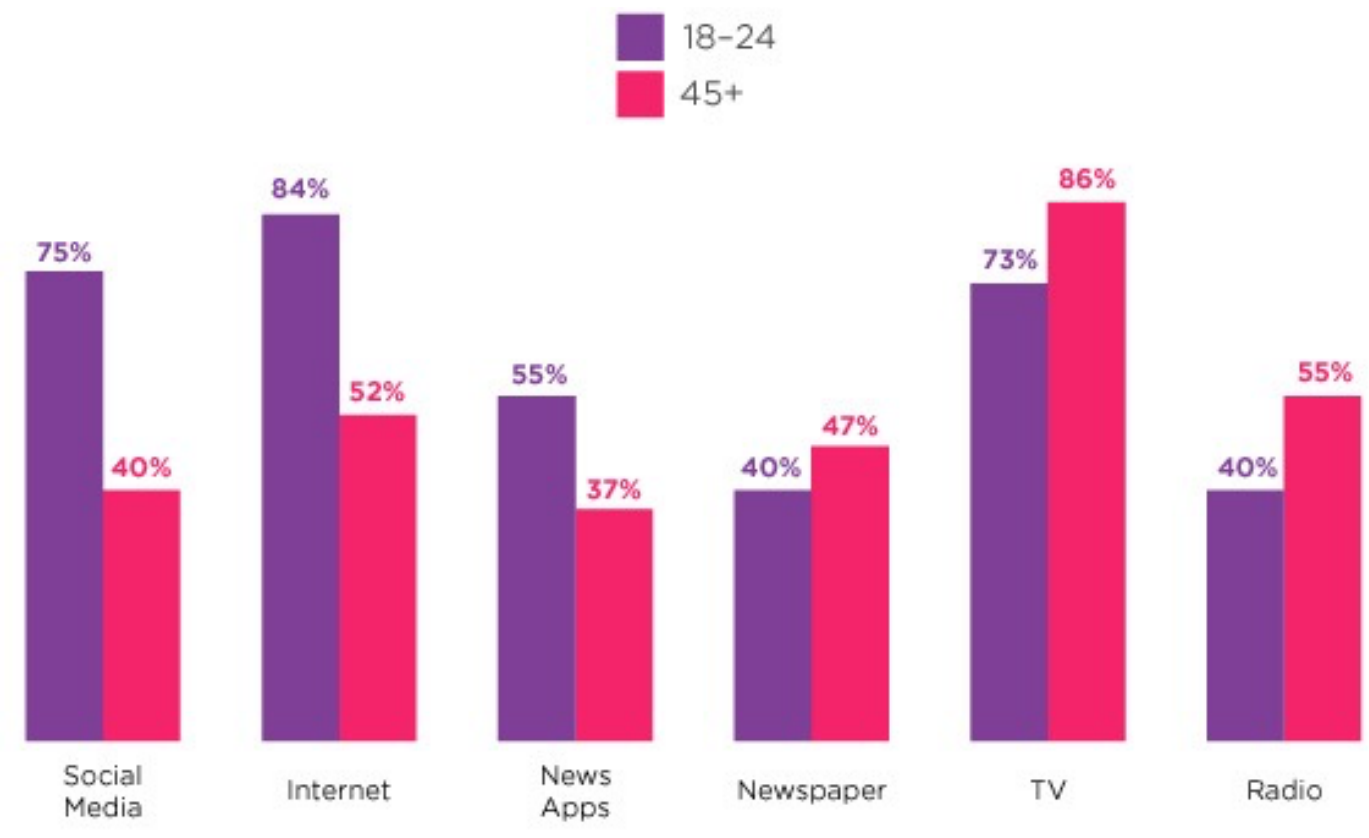

Figure 10: Importance of news sources, Northwestern University

Sarah Marshall

@SarahMarshall

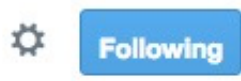

He's done it! WSJ Saudi correspondent @ahmed has hit 100,000 followers! He joined back in 2006... Saudi is the Twitter capital of the world

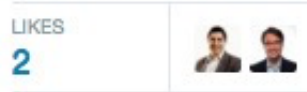

2:39 PM - 29 Apr 2015

Figure 11: Sarah Marshall, Twitter ${ }^{29}$ 


\section{Youth}

- TV remains the most popular news source for Arab Youth (60\%), followed by online $(40 \%)$.

Family and friends are more popular news sources than social, newspapers and radio.

- Direct messaging apps - like WhatsApp and Viber - are popular across all age groups; whereas the leading networks - Facebook, YouTube and Twitter - tend to skew young. ${ }^{30}$

- Social Media aside, the 16 country Arab Youth Study revealed the ubiquitous nature of digital technology among this cohort. $82 \%$ of young Arabs use the web daily. $77 \%$ own a smartphone.

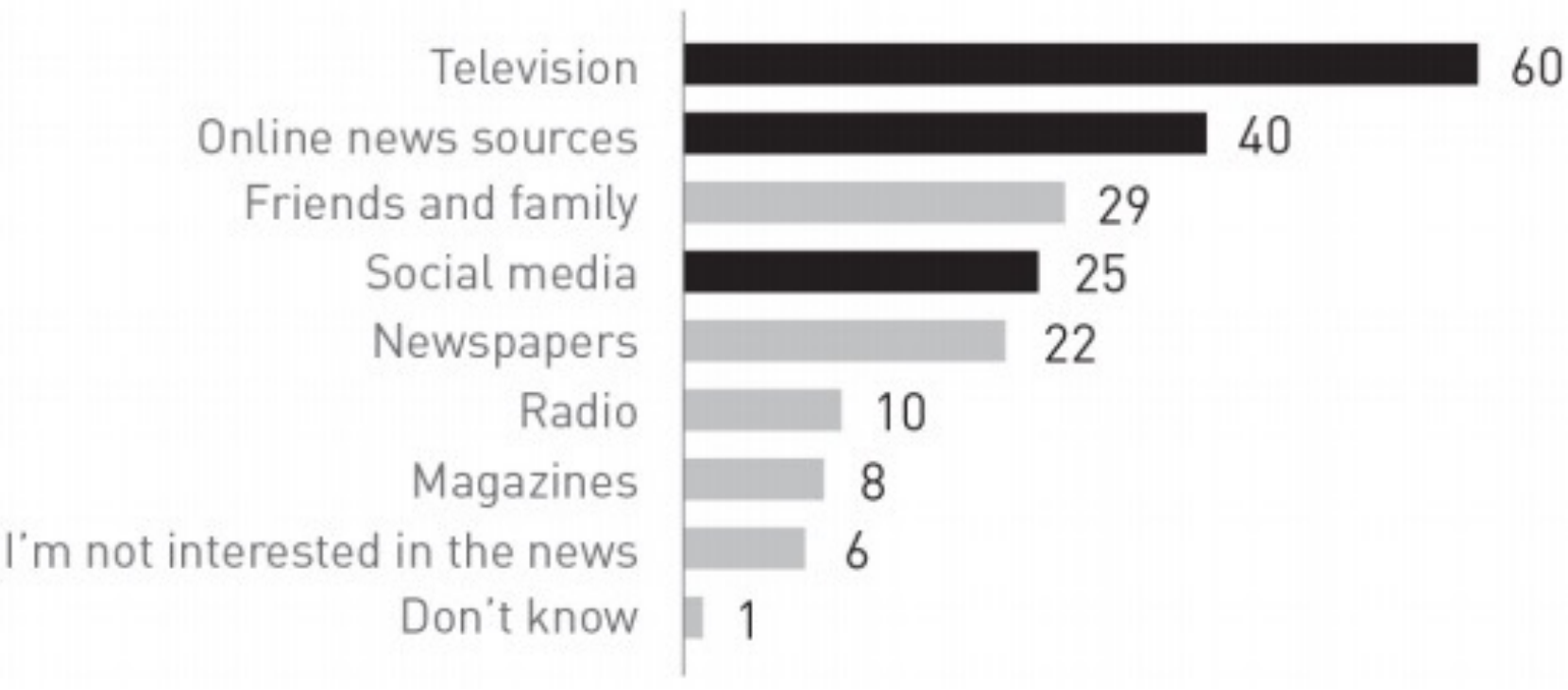

Figure 12: Where do you get your news from? Arab Youth Study

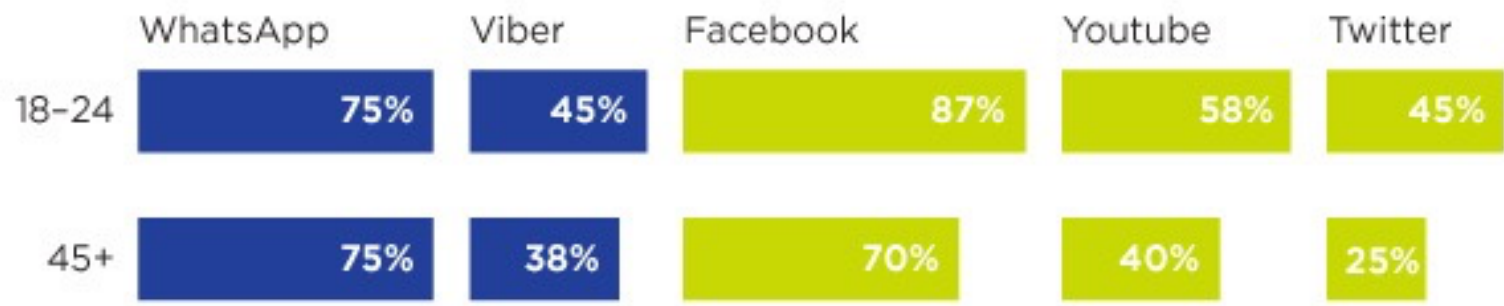

Base: Nationals, internet users only

Figure 13: Age profile of Top 5 social platforms in Egypt, Lebanon, Qatar Saudi Arabia, Tunisia and UAE, Northwestern University in Qatar 
- A Brookings Institute study, "The ISIS Twitter Census," reported ${ }^{31}$ at least 46,000 Twitter accounts were used by ISIS supporters, with Saudi Arabia home to the largest number of pro-ISIS accounts. ${ }^{32}$

- Saturday Night Live ${ }^{33}$ and social media users in the region, created various parody videos mocking Islamic State. ${ }^{34}$ Muslims also used Twitter to respond with humour to ISIS' call "to join the fight." ${ }^{35}$

- In December, some social media users also took to Twitter ${ }^{36}$ using the \#SueMeSaudi hashtag to draw parallels between Saudi Arabia and ISIS, with particular emphasis on their use of capital punishment. ${ }^{37}$

Mr Lee Jasper

(LeeJasper

20 +e Follow

Saudi Arabia and ISIS are one and the same. \#SueMeSaudi RT
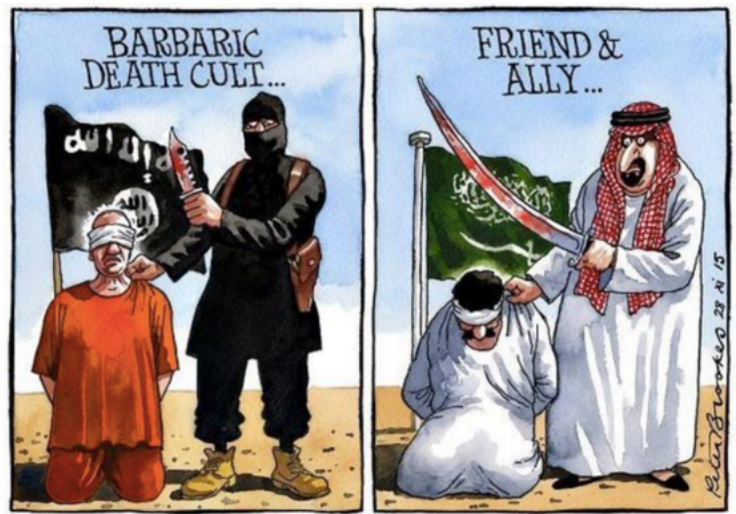

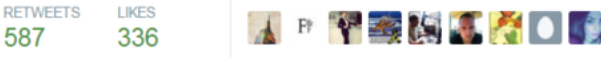

.Figure 14: Image via BBC Breaking 38

Location Claimed in Profile

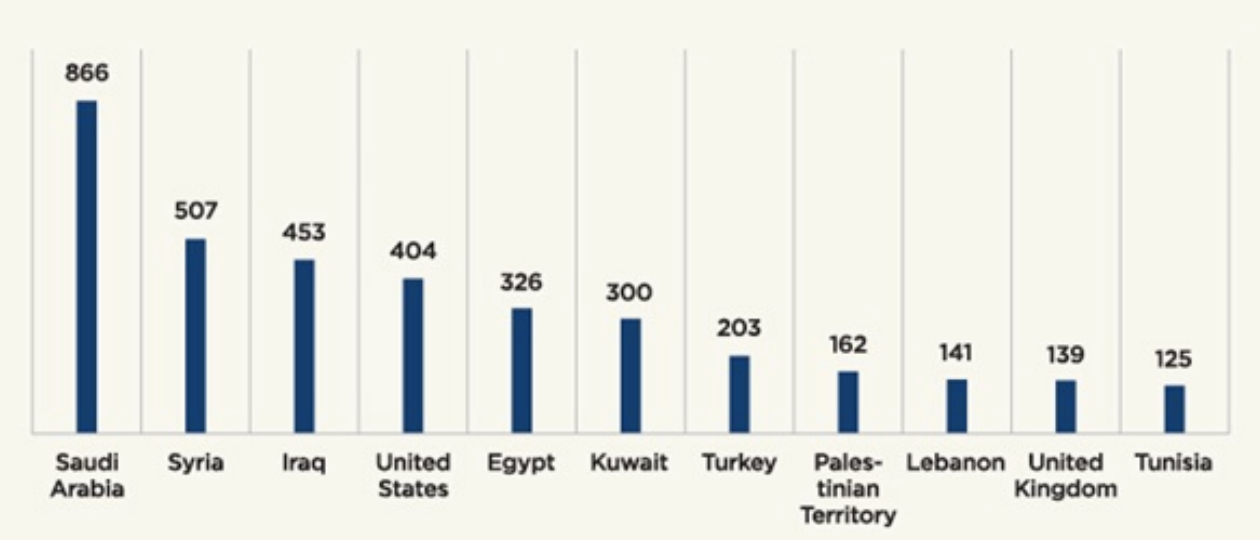

Figure 15: Claimed locations of pro-ISIS Twitter accounts. Image via The Brookings Institute ${ }^{39}$ 


\section{Freedom of Expression}

- The Pew Research Center found less support in the Middle East than other regions around the idea that "people can say what they want.... without state/gov censorship." ${ }^{40}$ Of the 38 nations studied, Palestinians were among the least likely to say "freedom of expression is very important." A median of $\mathbf{7 4 \%}$ across five Middle Eastern countries said people should be able to complain publicly about the government. However, In Turkey (39\%) and Jordan (26\%) significant numbers said the government should be able to prevent people from being critical of the state. ${ }^{41}$

- Twitter received the most content removal requests globally from the Turkish government, their transparency report (published in February 2015) revealed. Turkey submitted 477 take-down requests between July 1 - December 31 2014, more than all other countries combined (796 global total). ${ }^{42}$ The country's relationship with social media remains "complicated." 43

- Egyptian Doctors took to Facebook ${ }^{44}$ to highlight poor conditions in state hospitals. The graphic photos, the New York Times noted, include images of patients "surrounded by filth, stray cats, sewage, rodent droppings and snakes." ${ }^{45}$ (Be advised some of these photos are very unpleasant.)

- Saudi Arabia's Supreme Court upheld the sentence of 1,000 lashes and 10 years imposed on blogger Raif Badawi, ${ }^{46}$ following a 2012 arrest for "insulting Islam through electronic channels. ${ }^{\text {47 }}$

- An American expat was arrested in March after a "Facebook rant" about his employer in the United Arab Emirates. Although he posted the comments while in the US, he was arrested when he returned to the UAE. ${ }^{48}$

\section{Support for Free Speech, Press Freedom and Internet Freedom}

Regional median saying it is very important that

without state/gov't censorship in our country
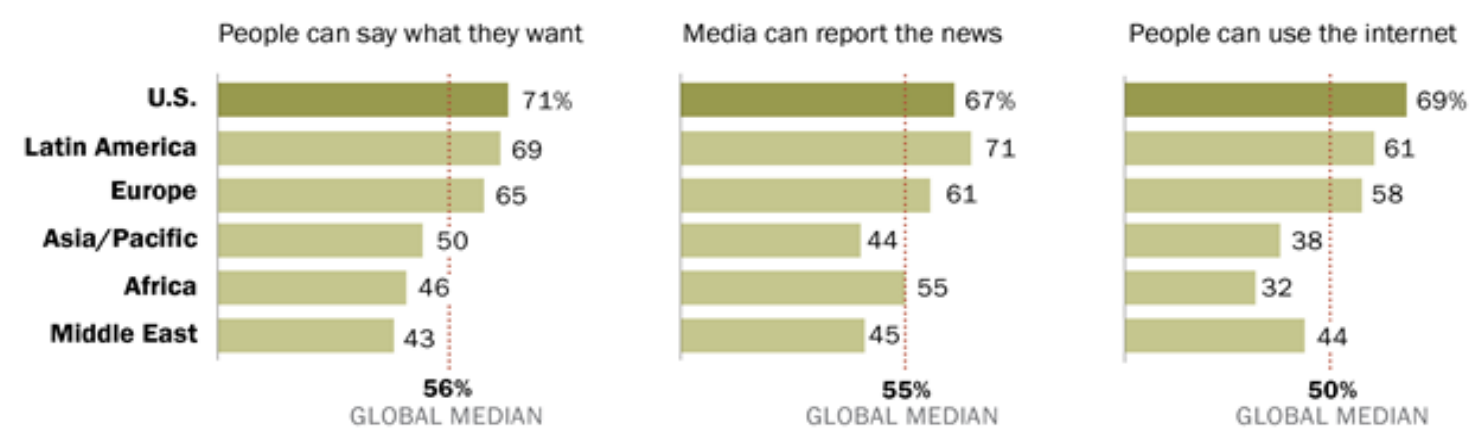

Note: Global median of 38 countries. Russia and Ukraine not included in Europe median.

Source: Spring 2015 Global Attitudes survey. Q56b, d, f.

PEW RESEARCH CENTER

Figure 16: Data via Pew Research Center ${ }^{49}$ 


\section{Further Reading}

Selected research recommendations:

- We Are Social: Digital, Social \& Mobile in 2015 (Jan 2015)

- WPP / TNS: The Arab Social Media Report 2015 (March 2015)

- Arab Youth Survey 2015: Presentation, White Paper, Top 10 Findings (April 2015)

- Northwestern University in Qatar: mideastmedia.org (April 2015)

- Pew Research Center: Global Support for Principle of Free Expression, but Opposition to Some Forms of Speech (Nov 2015)

- Damian Radcliffe: Social Media in the Middle East: The Story of 2014 (Jan 2015)

(also available on Scribd, SlideShare and Academia.edu)

Please also see previous annual round-ups which were produced whilst I worked for Qatar's Ministry of Information and Communications Technology (ictQATAR):

- Social Media in the Middle East: The Story of 2013 (English, Arabic)

- Social Media in the MENA - 2012 Review (English, Arabic)

Social Media in the Middle East: The Story of 2015 by Damian Radcliffe is licensed under a Creative Commons Attribution-NonCommercial-ShareAlike 4.0 International License.

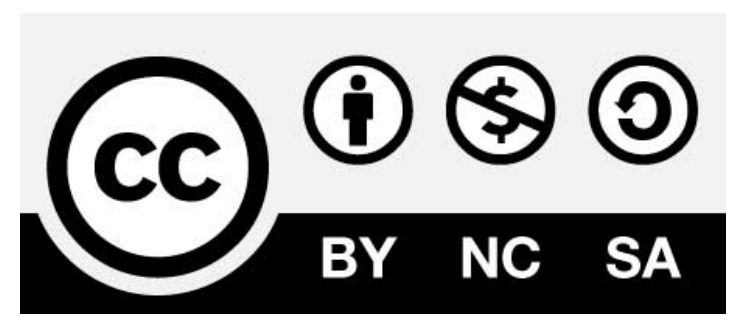


${ }^{1}$ See: https://www.washingtonpost.com/world/national-security/islamic-states-embrace-of-social-media-puts-tech-companies-in-abind/2015/07/15/0e5624c4-169c-11e5-89f3-61410da94eb1_story.html, http://fortune.com/2015/12/10/why-the-social-media-giants-cant-everwipe-out-isis-propaganda/ and others.

${ }^{2}$ http://www.slideshare.net/wearesocialsg/digital-social-mobile-in-2015/26-We_Are_Social_wearesocialsg_26SOCIAL

${ }_{3}^{3}$ http://www.mideastmedia.org/2015/chapter/social-media.html\#subchapter2

${ }^{4}$ https://www.google.com/url?sa=t\&rct=j\&q=\&esrc=s\&source=web\&cd=1\&ved=0ahUKEwiG4itiq3KAhUMzWMKHQitDFsQFggdMAA\&url=http\%3A\%2F\%2Fwww.wpp.com\%2Fgovtpractice\%2F \%2Fmedia\%2Fwppgov\%2Ffiles\%2Farabsocialmedi areport-2015.pdf\&usg=AFQjCNGQMdOeATiLkDmuh2XMtoqL jlzzw\&sig2=eEe7kvwUSZaXVOpn4x6NGg\&cad=rja

${ }_{5}^{5}$ http://www.jpost.com/Israel-News/Survey-Israelis-addicted-to-Whatsapp-dont-pay-for-streaming-movies-385980

${ }^{6}$ http://www.emirates247.com/business/technology/more-facebook-addicts-in-uae-compared-to-global-average-2015-03-18-1.584646

7 http://www.internetworldstats.com/stats5.htm

8 http://www.internetworldstats.com/stats1.htm

9 https://stepfeed.com/more-categories/big-news/social-media-users-question-why-beirut-doesnt-get-facebook-safety-check/ and

http://money.cnn.com/2015/11/15/technology/paris-attacks-facebook-safety-check/ + others.

${ }^{10} \mathrm{http} / / /$ www.bbc.com/news/world-middle-east-34805466

${ }_{11}$ http://allfacebook.com/northwestern-university-qatar-doha-film-institute-middle-east-study_b131129

12 https://www.linkedin.com/pulse/influence-visual-storytelling-rise-instagram-middle-east-ema-linaker

${ }_{13}^{13} \mathrm{https://www.searchenginejournal.com/instagram-sees-record-gains-hits-400-million-user-milestone/141756/}$

${ }_{14}^{14} \mathrm{https://stepfeed.com/business/media-advertising/the-middle-easts-love-for-instagram-including-its-adverts/}$

15 http://www.slideshare.net/lpsosMENA/digital-media-forum-2015 - 2014 data presented in mid-2015.

${ }_{16}$ http://english.alarabiya.net/en/media/digital/2015/04/23/Saudi-prince-s-Bentley-pledge-to-fighter-pilots-gets-global-coverage.html

17 http://www.bbc.com/news/blogs-trending-32417773

${ }_{18}^{18}$ https://twitter.com/Othmanbay/status/590844910661697536

19 http://www.bbc.com/news/blogs-trending-33478729

20 https://twitter.com/adoomy4life/status/620809813652541440

${ }^{21}$ http://english.alarabiya.net/en/media/2015/04/20/Hilarious-RiyadhLife-snapchats-trend-as-users-laugh-off-stereotypes.html

22 http://knowyourmeme.com/memes/riyadh-life

${ }_{23} \mathrm{http}: / /$ m.dubaiprnetwork.com/pr.asp?pr=99891 data provided by Facebook.

${ }_{24}^{24}$ http://www.buzzfeed.com/alexkantrowitz/why-periscope-is-going-wild-in-turkey\#.mvNgQR9nBj

25 https://blog.twitter.com/2015/introducing-periscope

${ }^{26}$ Via email from Momina Chaudhry, Memac Ogilvy. Also available in Arabic at: http://google-arabia.blogspot.ae/2015/12/youtube.html

${ }^{27} \mathrm{http}: / /$ google-arabia.blogspot.ae/2015/12/youtube.html - translations via Google Translate.

${ }^{28}$ http://www.arabyouthsurvey.com/

${ }^{29}$ https://twitter.com/sarahmarshall/status/593529945529274369

30 http://www.mideastmedia.org/2015/chapter/social-media.html\#subchapter1

${ }_{31} \mathrm{http}: / /$ www.brookings.edu/research/papers/2015/03/isis-twitter-census-berger-morgan

32 https://www.washingtonpost.com/world/national-security/in-a-propaganda-war-us-tried-to-play-by-the-enemys-rules/2015/05/08/6eb6b732e52f-11e4-81ea-0649268f729e_story.html

${ }^{33} \mathrm{https://www.youtube.com/watch?v=LL2fazw5Y9k \& app=desktop}$

${ }_{34}$ http://america.aljazeera.com/articles/2015/3/2/SNL-parody-of-isil-made-headlines-but-its-far-from-original.html

35 https://twitter.com/iyad_elbaghdadi/status/680776223606333440

${ }_{36}^{36}$ http://www.bbc.com/news/blogs-trending-34966066

${ }^{37} \mathrm{http} / / /$ www.dailymail.co.uk/news/article-3340697/SueMeSaudi-hashtag-taunting-Arabian-nation-threatening-legal-action-comparisons-ISISbeheading-executions-sweeps-Twitter.html

${ }^{38}$ http://www.bbc.com/news/blogs-trending-34966066

39 http://www.brookings.edu/research/papers/2015/03/isis-twitter-census-berger-morgan

${ }^{40}$ http://www.pewglobal.org/2015/11/18/global-support-for-principle-of-free-expression-but-opposition-to-some-forms-of-speech/

${ }^{41}$ http://www.pewglobal.org/files/2015/11/Pew-Research-Center-Democracy-Report-FINAL-November-18-2015.pdf

42 http://www.statista.com/chart/3217/twitter-content-removal-requests/

${ }^{43}$ http://www.bbc.co.uk/blogs/collegeofjournalism/entries/738f63e8-b73e-45f8-8700-620808b9d45e and

http://www.digitalnewsreport.org/essays/2015/how-turkey-uses-social-media/

${ }^{44}$ https://www.facebook.com/lawgehnosurprise/photos_stream

45 http://www.nytimes.com/2015/06/13/world/middleeast/egyptian-doctors-shame-government-with-facebook-images-of-filthy-state-runhospitals.html? $r=0$

${ }^{46} \mathrm{http}: / /$ www.independent.co.uk/news/world/middle-east/saudi-arabia-upholds-blogger-raif-badawis-sentence-of-1000-lashes-and-10-years-injail-10303069.html

${ }^{47}$ http://www.bbc.com/news/world-middle-east-33039815

${ }^{48}$ http://www.bbc.com/news/technology-31692914

${ }_{49} \mathrm{http} / / /$ www.pewglobal.org/2015/11/18/global-support-for-principle-of-free-expression-but-opposition-to-some-forms-of-speech/ 